\title{
Numerical Analysis of A Nonlinear Elastic Composite Leaf Spring
}

\author{
Doğrusal Olmayan Elastik Kompozit Yaprak Yay Sayısal Analizi \\ Osman ÖREN ${ }^{1}$ (D) İrem Beyza EKİCi ${ }^{1}$ \\ ${ }^{I}$ Marmara Üniversitesi, Makine Mühendisliği Bölümü, 34722, İstanbul, Türkiye
}

\begin{abstract}
In this study, numerical analyzes of a composite spring with a nonlinear elastic force-displacment relationship were performed. Due to the lightness and durability of composite materials, their use in the automotive industry is increasing and production methods allow for a high performance spring design. The behavior of a pair of composite leaf springs working in tandem with the cross-section profiles of the leaf springs to be obtained by using the involute curve of the spur gear pairs under load was examined in detail by numerical method, and the desired behavior was obtained. In the analyzes performed using Ls-Dyna software, samples were produced and many mechanical tests were performed for the determination of material parameters. The results obtained from these tests were used as the required material parameters in numerical analysis. The leaf spring thickness that will give the desired non-linear elastic behavior under $400 \mathrm{~N}$ load used in numerical analysis has been determined and successfully targeted force-elongation behavior has been created.
\end{abstract}

Keywords: Composite, leaf Spring, nonlinear elastic, FEM

\section{$\ddot{\mathbf{O z}}$}

Bu çalışmada, doğrusal olmayan elastik kuvvet-yer değiştirme ilişkisine sahip bir kompozit yayın sayısal analizleri yapılmıştır. Kompozit malzemelerin hafifliği ve dayanıklılı̆̆ı nedeniyle otomotiv endüstrisinde kullanımları artmakta ve üretim yöntemleri yüksek performanslı bir yay tasarımına olanak sağlamaktadır. Düz dişli çiftlerinin involüt eğrisi kullanılarak elde edilecek yaprak yayların kesit profilleri ile tandem halinde çalışan bir çift kompozit yaprak yayın yük altındaki davranışı sayısal yöntemle detaylı olarak incelenmiş ve istenilen davranış elde edilmiştir. Elde edilen. Ls-Dyna yazılımı kullanılarak yapılan analizlerde numuneler üretilmiş ve malzeme parametrelerinin belirlenmesi için birçok mekanik test yapılmıştır. Bu testlerden elde edilen sonuçlar, sayısal analizlerde gerekli malzeme parametreleri olarak kullanılmıştır. Sayısal analizde kullanılan $400 \mathrm{~N}$ yük altında istenilen doğrusal olmayan elastik davranışı verecek yaprak yay kalınlığı belirlenmiş ve başarılı bir şekilde hedeflenen kuvvet-uzama davranışı oluşturulmuștur.

Anahtar Kelimeler: Kompozit, Yaprak Yay, Doğrusal Olmayan Elastik FEM

\section{INTRODUCTION}

Thousands of products have been used in design and production of assemblies. The number of materials can be used for design purpose are so much that an engineering study is necessary to select the best one. Because the characteristics and properties of materials play very critical role in design, the importance of material selection has been grown day by day. The best fit material selection for necessary application provides the most suitable function and maximum benefit. Part design, price and quality of products are generally determined by selecting proper material. Although there are thousands of materials in the world; the developing and growing industry requirements need new material alternatives. Today, some materials which are so significant in the past, are demanded so limited [1].

Cost, lightweight materials, energy efficiency and function are key issues in material selection in vehicle sector. In this study, alternative composite structures will be inspected in detailed in stead of conventional steel suspension systems in automotive industry. Composite materials have a lot of different types which vary in their mechanical properties, costs, functions and weights. When the commonly used fiber reinforcements are considered in general automotive applications, it will be seen that glass fibers, aramid fibers and carbon fibers are highly preferred in this industry thanks to their superior behaviors [2]. These fibers have different mechanical behaviours which may be used in various applications and industries with various combinations. In our thesis, it will be studied on composite structure manufacturing, which will be used in suspension systems for automotive industry, by using aramid fibre reinforced laminated composite. The material selection will be one of the crucial topics. Firstly, it will be discussed which reinforcement material will be optimum type for suspension system [3]. One of the most important properties for suspension is fatigue resistance. Therefore, aramide fibers are selected in this study. It is expected that this system also has high fatigue resistance. Aramid fibers possess excellent vibration damping resistance compared to carbon and glass fibers. Therefore, characteristics of polymer matrix aramid composites are studied in literature [4]. 
The automotive industry emphasizes lightweight and energy efficient materials [5]. This interest in lightweight and energy efficient parts has opened a significant door to generalize these items and to use in new sectors. When composite material types are considered by means of weight in automotive sector, aramid fibre reinforced laminated composite weights take attention with their low densities. Compared to glass and carbon reinforced laminated composites, the aramid reinforced structures have low densities. At the present time which energy demand increased and energy sources decreased, fuel consumption for automotive industry has had a particular importance.
Fuel consumption is decreased by less lightweight vehicles. This situation is required to decrease the automotive part weights. Therefore, proper alternative lightweight material investigations have been continuing. As a solution, composite materials have been enhancing day by day their usage ratio in automotive industry. Automotive part durability plays an important role beside their lightness. Hence, material tensile strength to weight is the main criterian by considering fatigue resistance and cost requirement for composite suspension structure in material selection. The comparison of these commonly used fiber properties are indicated in Table 1.1.

Table 1.1. Comparison of fiber properties [7]

\begin{tabular}{|c|c|c|c|c|c|c|c|c|c|c|c|c|c|c|c|}
\hline & Symbol & Units & $\begin{array}{l}\text { Std CF } \\
\text { Fabric }\end{array}$ & $\begin{array}{l}\text { HMCF } \\
\text { Fabric }\end{array}$ & $\begin{array}{l}\text { E glass } \\
\text { Fabric }\end{array}$ & $\begin{array}{l}\text { Kevlar } \\
\text { Fabric }\end{array}$ & $\begin{array}{l}\text { Std CF } \\
\text { UD }\end{array}$ & $\begin{array}{l}\text { HMCF } \\
\text { UD }\end{array}$ & $\begin{array}{l}\text { M55** } \\
\text { UD }\end{array}$ & $\begin{array}{l}\text { E glass } \\
\text { UD }\end{array}$ & $\begin{array}{l}\text { Kevlar } \\
\text { UD }\end{array}$ & $\begin{array}{l}\text { Boron } \\
\text { UD }\end{array}$ & $\begin{array}{l}\text { Steel } \\
\text { S97 }\end{array}$ & $\begin{array}{l}\text { Al. } \\
\text { L65 }\end{array}$ & $\begin{array}{l}\text { Tit. dtd } \\
5173\end{array}$ \\
\hline Young's Modulus $0^{\circ}$ & E1 & $\mathrm{GPa}$ & 70 & 85 & 25 & 30 & 135 & 175 & 300 & 40 & 75 & 200 & 207 & 72 & 110 \\
\hline Young's Modulus $90^{\circ}$ & E2 & GPa & 70 & 85 & 25 & 30 & 10 & 8 & 12 & 8 & 6 & 15 & 207 & 72 & 110 \\
\hline In-plane Shear Modulus & G12 & GPa & 5 & 5 & 4 & 5 & 5 & 5 & 5 & 4 & 2 & 5 & 80 & 25 & \\
\hline Major Poisson's Ratio & v12 & & 0.10 & 0.10 & 0.20 & 0.20 & 0.30 & 0.30 & 0.30 & 0.25 & 0.34 & 0.23 & & & \\
\hline Ult. Tensile Strength $0^{\circ}$ & $\mathrm{Xt}$ & MPa & 600 & 350 & 440 & 480 & 1500 & 1000 & 1600 & 1000 & 1300 & 1400 & 990 & 460 & \\
\hline Ult. Comp. Strength $0^{\circ}$ & $\mathrm{Xc}$ & MPa & 570 & 150 & 425 & 190 & 1200 & 850 & 1300 & 600 & 280 & 2800 & & & \\
\hline Ult. Tensile Strength $90^{\circ}$ & Yt & MPa & 600 & 350 & 440 & 480 & 50 & 40 & 50 & 30 & 30 & 90 & & & \\
\hline Ult. Comp. Strength $90^{\circ}$ & Yc & $\mathrm{MPa}$ & 570 & 150 & 425 & 190 & 250 & 200 & 250 & 110 & 140 & 280 & & & \\
\hline Ult. In-plane Shear Stren. & S & $\mathrm{MPa}$ & 90 & 35 & 40 & 50 & 70 & 60 & 75 & 40 & 60 & 140 & & & \\
\hline Ult. Tensile Strain $0^{\circ}$ & ext & $\%$ & 0.85 & 0.40 & 1.75 & 1.60 & 1.05 & 0.55 & & 2.50 & 1.70 & 0.70 & & & \\
\hline Ult. Comp. Strain $0^{\circ}$ & exc & $\%$ & 0.80 & 0.15 & 1.70 & 0.60 & 0.85 & 0.45 & & 1.50 & 0.35 & 1.40 & & & \\
\hline Ult. Tensile Strain $90^{\circ}$ & eyt & $\%$ & 0.85 & 0.40 & 1.75 & 1.60 & 0.50 & 0.50 & & 0.35 & 0.50 & 0.60 & & & \\
\hline Ult. Comp. Strain $90^{\circ}$ & eyc & $\%$ & 0.80 & 0.15 & 1.70 & 0.60 & 2.50 & 2.50 & & 1.35 & 2.30 & 1.85 & & & \\
\hline Ult. In-plane shear strain & es & $\%$ & 1.80 & 0.70 & 1.00 & 1.00 & 1.40 & 1.20 & & 1.00 & 3.00 & 2.80 & & & \\
\hline Thermal Exp. Co-ef. $0^{\circ}$ & Alpha1 & Strain/K & 2.10 & 1.10 & 11.60 & 7.40 & -0.30 & -0.30 & -0.30 & 6.00 & 4.00 & 18.00 & & & \\
\hline Thermal Exp. Co-ef. $90^{\circ}$ & Alpha2 & Strain/K & 2.10 & 1.10 & 11.60 & 7.40 & 28.00 & 25.00 & 28.00 & 35.00 & 40.00 & 40.00 & & & \\
\hline Moisture Exp. Co-ef $0^{\circ}$ & Beta1 & Strain/K & 0.03 & 0.03 & 0.07 & 0.07 & 0.01 & 0.01 & & 0.01 & 0.04 & 0.01 & & & \\
\hline Moisture Exp. Co-ef $90^{\circ}$ & Beta2 & Strain/K & 0.03 & 0.03 & 0.07 & 0.07 & 0.30 & 0.30 & & 0.30 & 0.30 & 0.30 & & & \\
\hline Density & & $\mathrm{g} / \mathrm{cc}$ & 1.60 & 1.60 & 1.90 & 1.40 & 1.60 & 1.60 & 1.65 & 1.90 & 1.40 & 2.00 & & & \\
\hline
\end{tabular}

For the weight reduction, carbon and aramid mixture can be preferred instead of sole glass fibers; if there is no cost concern. If high strength is asked for, aramid fiber reinforced laminated composites can be preferred. If high rigidity is asked for, carbon fiber reinforced laminated composites are preferred [8]. Besides, composite fiber costs will be play an important role in material selection. Carbon reinforced composites are more expensive than aramid and glass, relatively. Carbon reinforced parts are utilized widely in automotive sector. Usage ratio increases progressively in more luxurious automotive concept thanks to their high stiffness, lightness and high strength.

High cost of these materials restricts their wide usage area in standard, regular cars. In low price oriented vehicles, aramid reinforement composite parts may be used instead of carbon reinforement composite parts, if their usage areas are proper.

Springs are machine elaments manufactured from elastic stiff materials such as steel. They are used in 
many assemblies to generate expected force-deflection characteristic. They are also very critical parts for storing and releasing potential energy. Mechanical motions that can be obtaiened by employing springs are generaly results of a push-pull or a twist-untwist force. They are mainly store energy and then release it [9]. The spring's performance in uniaxial loading is characterized by the relation between force $(\mathrm{F})$ and the corresponding displacement (d) obtained on it. When this relation is plotted the slope of the F-d curve is the spring rate or stiffness denoted by $\mathrm{k}$. The slope of a spring may be a line or curve geometrically. If it is line, the spring is called as linear elastic one. Otherwise, it is curve and spring is nonlinear elastic. Linear springs obey the Hooke's Law, F = k d. When we talk about the design of springs, we actually mean linear springs. Because the majority of springs are linear springs. Since the applied force in a nonlinear spring is not proportional to its deflection progressive hardening or softening may occur. The occurance of them depends on the design of spring and its material.

Another spring type is the leaf spring which is interested in this study too. Mechanism of forcedeflection behavior may be explained by 3-point bending, distributed load bending or simply cantilever beam bending. The design of composite spring in this study is based on cantilever beam. For that kind of elements, the relation between force and displament is can be written as,

$$
\delta=\frac{F L^{3}}{3 E I}
$$

Where $\mathrm{L}$ is the length of beam, E and I are elastic modulus and moment of inertia respectively.

If a nonlinear spring shows an increasing spring rate as the spring deflection continues, then this spring is said to be a progressive one. In this phenomenon, it shows a gradually hardening reaction as the spring gets bended for catilever type leaf springs. On contrary, there are also degressive nonlinear springs. They progressively decrease their spring rates as the spring deflection increases. This is a softening behavior. The F-d relationship of a nonlinear spring can be controlled by its design and application. The design methods for these springs for uniaxial loading of coil springs and bending of leaf springs are studied in literature in detail. But because of the design methods of linear springs are not directly applicable for nonlinear springs due to nonlneraity problems, it is necessary to spend more time and effort for designing of nonlinear springs.

In this study, in order to obtain softening or hardening type spring in cantilever beam element the contact mechanism of spur gears is selected and involute profile relation tried to be obtained by using two leaf cantilever spring contacting to each other on their fee ends. The leaf springs have identical curved geometry.
Since during the bending of cantilever beam under loading the first beam rolls on the other. The moment arm changes progressively and therefore gradual hardening and softening can be obtained easily. Then the spring constant can be controlled easily by the thickness of plates. This will lead to design of a spring for the load given. For that kind of design and loading it is difficult to formulate the force and displacement relation. Instead the experimenatal and numerical studies employed and compared to each other for the sake of validity.

\section{MATERIALS AND METHODS}

\subsection{Determination of Mechanical Parameters}

Composite materials have not constant and defined mechanical properties. They can not be obtained directly from material mechanical property libraries in literature and analysis softwares. Their mechancial properties vary according to composite constituent material type, material usage rate, size, production method, etc. To specify the physical characteristics of aramid reinforcement laminated structure; some physical tests are applied to composite specimens. These tests are tensile, compression and shear tests. All mechanical tests are applied in Shimadzu AGS-X Series Universal Electromechanical test device $(50 \mathrm{kN}$ table top model) at Marmara University. This device can apply tensile, compression, shear, bending and fatigue tests etc, as shown in figure 1.

Aramid fiber reinforced laminated composite specimens were produced for mechanical testing. Tests peformed are shown in figure 1. All specimens were produced with VARTM method (Vacuum Assisted Resin Transfer Molding). 16 aramid fabric layers and epoxy were used for aramid composite plates. The thickness of these plates are uniform and is $3.8 \mathrm{~mm}$. The thickness of the leaf spring designed in this study is also $3.8 \mathrm{~mm}$. These plates are then cut into specimens according to test specification (American Society for testing and materials - ASTM).

In tensile test, tensile test specimen is mounted between the jaws of test machine and then loading is performed. Tensile test is applied to composite test specimen according to ASTM tensile test standard. (D3039/D3039M - 17) Test specimen has rectangular geometry and its cross-section is constant all over the specimen length. Tensile test is basic test to determine the mechanical properties. Specimen width and length are $25 \mathrm{~mm}$ and $250 \mathrm{~mm}$ in the tensile test. [11]

In compression test, specific compression text fixture is used. It is mounted to test first as shown in figure $1 \mathrm{~b}$ and then compression test specimen is assembled to compression test fixture. Compression test is peformed according to ASTM compression test standard (D6641/D6641M - 16) [11]. The composite specimen has rectangular cross section. The specimen width and length are acceptable with respect to corresponding 
ASTM standard. Specimen width and length are $13 \mathrm{~mm}$ and $140 \mathrm{~mm}$ respectively [5]. Thickness is $3.8 \mathrm{~mm}$ for all test specimens.
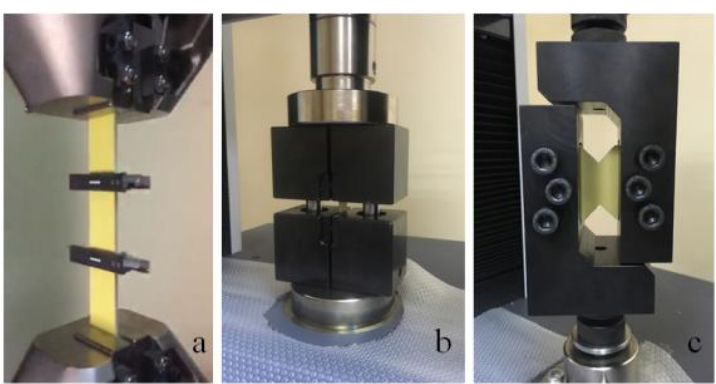

Figure 1. Mechanical tests for aramid reinforcement laminated composite material:

a) Tensile test b) Compression test c) Shear test

In shear test, shear test fixture is employed and mounted to test machine and then test specimen is assembled to the test fixture. Shear loading is applied to test specimen via fixture according to ASTM shear test standard (D7078/D7078M - 12) [12]. The test specimen has rectangular geometry like other test type specimens have. But these shear test specimens have symmetrical centered V-notches. The test specimen thickness is same with original composite leaf spring thickness and is $3.8 \mathrm{~mm}$. The specimen width and length are $56 \mathrm{~mm}$ and $76 \mathrm{~mm}$ respectively in the shear test.

\subsection{Bending Test}

The bending tests are usually utilized to specify the material bending strength. The bending strength is the force amount which a material can act and change shape without rupture. Bending test is also used as a mechanical property for some materials and described as the ability to resist deformation under load, as well [13].

Bending tests have become an important test method in materials science and R\&D studies together with ever increasing demand for high strength materials. Young's modulus and bending stress are the characteristics which have significant duties for the bending durability of test sample.

Various technological devices or objects which are subjected different effects such as tensile, compression, bending and fatigue forces, etc., are used often at the present time. Some tests like tensile test, bending test and compression test etc. are applied to these products to see effects of these forces.

In this study, bending test will be applied to test specimen. The bending test simulates the working concept in test specimens which are subjected to many bending cycles in daily usage. One of the commonly used bending types is cantilever bending, this bending type is preferred because of simplicity in investigations. Another type is three-point bending test; this test is used often to obtain mechnaical values, as well. Lastly four-point flexural test is also preferred not only in non-composite materials but also in composite materials. In this thesis, cantilever bending system will be used in bending tests. Not only one but also two cantilever bending systems which are aramid fiber reinforced laminated composite structure, are mounted to test apparatus. These composite structures together resist to bending loading under bending test machine.

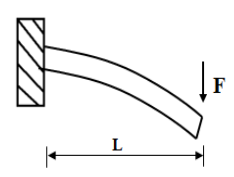

Cantilever bending

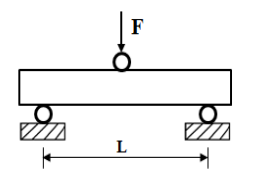

Three point bending

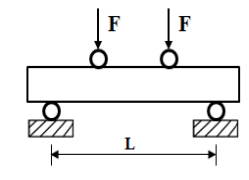

Four point bending
Figure 2. The some of the commonly used bending types

The desirable bending forces are applied to the top of the composite structure in various strokes. Two composite structures have to be assemblied reverse and parallel to each other into test apparatus in this mechanism as shown in figure 3. It is aimed that the lower lower leaf spring supports upper leaf spring during bending loading.

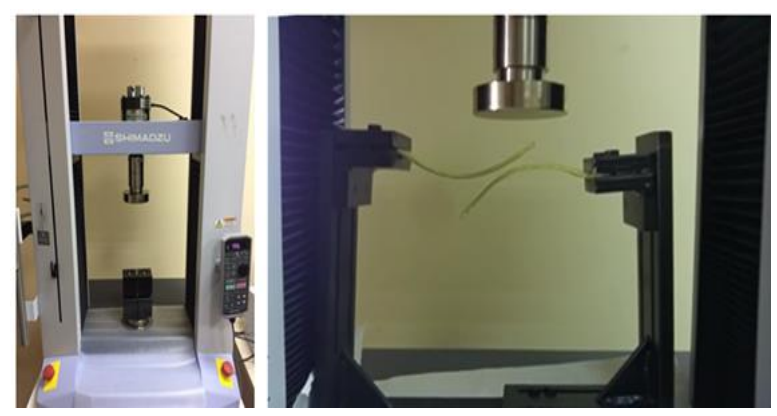

Figure 3. Bending Test

The load is applied to the tip of upper one. The bahvior of upper spring is linear elastic till the contact is achieved. After that point since the support point is not constant instead it is varying depending on the the load, behavior of both springs become non-linear elastic. The behavior of the mate of two springs arranged as in figure 3 is complicated but as a whole it can be said nonlinear elastic.

\subsection{Numerical Simulation Force-Displacment Behavior Leaf}

In this thesis, the experimental results under bending test machine were compared with numerical results which were obtained in ANSYS LS-DYNA software. A mechanism which contains two composite leaf springs, was obtained. It was aimed that these springs have a high damping force and non-linear elastic characteristic and to get an alternative system in suspension systems.

The model geometry and material parameters are defined in Ansys Ls-Dyna program. The boundary 
conditions are also defined. There are a lot of different material models for metals, plastics, glasses, composites and etc. in LS-Dyna. The some of the available material models for composites are indicated in figure 4. Some constituent models give more accurate results in case of solid or shell material. Because the spring thickness is not so thin, the shell module can not be applied. In solid module, the results can be obtained also in thickness direction. In this study, MAT 22, MAT 54/55 and MAT 59 models which have solid model for composite materials, were tried and it was observed that MAT 59 model is best fit with experimental values $[14,16]$.

\begin{tabular}{|c|c|c|c|}
\hline Material Model & Element & Failure factor & Comment \\
\hline $\begin{array}{l}\text { MAT_022: } \\
\text { COMPOSITE_DAMAGE }\end{array}$ & $\begin{array}{l}\text { Shell, } \\
\text { Tshell, } \\
\text { Solid }\end{array}$ & Chang-Chang & $\begin{array}{l}\text { No fibre compression failure } \\
\text { Simple brittle model. No crash front } \\
\text { algorithm }\end{array}$ \\
\hline $\begin{array}{l}\text { MAT_054/55: } \\
\text { ENHANCED_COMPOSITE_ } \\
\text { DAMAGE_ }\end{array}$ & \begin{tabular}{|l|} 
Shell, \\
Tshell \\
Solid \\
\end{tabular} & $\begin{array}{l}\text { 54: Chang-Chang } \\
\text { 55: Tsai-Wu }\end{array}$ & $\begin{array}{l}\text { Enhanced versions of MAT_022 } \\
\text { Crash front algorithm }\end{array}$ \\
\hline $\begin{array}{l}\text { MAT_058: } \\
\text { LAMINATED_COMPOSITE_ } \\
\text { FABRIC }\end{array}$ & $\begin{array}{l}\text { Shell, } \\
\text { Tshell }(1,2)\end{array}$ & Modified Hashin & $\begin{array}{l}\text { Smooth stress-strain relation } \\
\text { Non-linear shear behaviour } \\
\text { Minimum stress limit factor } \\
\text { Exponential softening }\end{array}$ \\
\hline $\begin{array}{l}\text { MAT_059: } \\
\text { COMPOSITE_FAILURE_- } \\
\text { MODEL_(Plasticity Based) }\end{array}$ & \begin{tabular}{|l|} 
Shell, \\
Tshell, \\
Solid, SPH \\
\end{tabular} & Modified Hashin & $\begin{array}{l}\text { Similar to MAT_054 } \\
\text { Crash front algorithm } \\
\text { Minimum stress limit factor }\end{array}$ \\
\hline $\begin{array}{l}\text { MAT_158: } \\
\text { RATE_SENSITIVE_- } \\
\text { COMPOSITE_FABRIC } \\
\end{array}$ & $\begin{array}{l}\text { Shell, } \\
\text { Tshell }\end{array}$ & Modified Hashin & $\begin{array}{l}\text { Same as MAT_058 } \\
\text { Rate sensitive }\end{array}$ \\
\hline $\begin{array}{l}\text { MAT_261: } \\
\text { LAMINATED_FRACTURE_ } \\
\text { DAIMLER_PINHO }\end{array}$ & $\begin{array}{l}\text { Shell, } \\
\text { Tshell, } \\
\text { Solid }\end{array}$ & Pinho & $\begin{array}{l}\text { Physical based failure criteria } \\
\text { Continuum damage model } \\
\text { Linear softening evolution based on } \\
\text { fracture toughness }\end{array}$ \\
\hline $\begin{array}{l}\text { MAT_262: } \\
\text { LAMINATED_FRACTURE_ } \\
\text { DAIMLER_CAMANHO }\end{array}$ & $\begin{array}{l}\text { Shell, } \\
\text { Tshell, } \\
\text { Solid }\end{array}$ & Camanho & $\begin{array}{l}\text { Physical based failure criteria } \\
\text { Continuum damage model } \\
\text { Bi-linear/linear softening evolution } \\
\text { based on fracture toughness }\end{array}$ \\
\hline
\end{tabular}

Figure 4. Available material models for composite materials in Ls-Dyna [58]

MAT 59 model is based on Hashin's criteria. Because of it its uncomplicated interface and usage easiness, this method is widely used within structural investigations for composites. Because this criterion does not become suitable with experimental outcomes so good everytime, base hypotheses which Hashin proposed, are re-investigated currently. This method used in the tension fiber and tension matrix mode is modified relying on physical evaluations and in this study, the modified Hashin criteria will be used. [17].

Because it is intended to observe the composite failure of springs and the material is solid, the material model is selected as Material 59. The selected material model specifies material behaviour in the simulation. This model determines also the mechanical behaviour method in failure initiation.

All mechanical properties of the composite material obtained from experiments are used in dynamic simulations. These parameters are entered into material card of the program as shown in figure 5. The geometry of springs and boundary conditions are defined in as well. Automatic surface to surface contact option is preffered. It is main focus to observe the displacement vs. time in this simulation and compare with the results in experimental bending results and to see whether or not non-linear elastic characteristic in composite leaf springs is obtined.

\begin{tabular}{|c|c|c|c|c|c|c|c|c|}
\hline$\$$ & $\underset{1}{\operatorname{mid}}$ & $\begin{array}{r}\text { ro } \\
14400 \mathrm{E}-8\end{array}$ & 10130.00 & $\begin{array}{r}\text { eb } \\
10130.00\end{array}$ & $\begin{array}{r}\mathrm{ec} \\
6066.000\end{array}$ & $\begin{array}{r}\text { prba } \\
0.15400\end{array}$ & prca & prcb \\
\hline$\$$ & & & & & aopt & maflag & & \\
\hline$\$$ & $\begin{array}{r}30.000 \\
\text { xp }\end{array}$ & $\begin{array}{r}916.000 \\
y p\end{array}$ & $\begin{array}{r}916.000 \\
\text { zp }\end{array}$ & $\begin{array}{r}0.0 \\
\text { a1 }\end{array}$ & $\begin{array}{r}0.0 \\
\text { d2 }\end{array}$ & $\begin{array}{r}1.000 \\
\text { a3 }\end{array}$ & & \\
\hline & 0.0 & 0.0 & 0.0 & 0.0 & 0.0 & 0.0 & & \\
\hline$\$$ & & v2 & v3 & & & d3 & beta & \\
\hline & 0.0 & 0.0 & 0.0 & 1.000 & 1.000 & 1.000 & 0.0 & \\
\hline$\$$ & sba & & $\mathrm{scb}$ & xxc & yyc & $2 z \mathrm{C}$ & & \\
\hline & $\begin{array}{r}30.000 \\
x \times t\end{array}$ & $\begin{array}{r}78.000 \\
\text { yyt }\end{array}$ & $\begin{array}{r}78.000 \\
\mathrm{zzt}\end{array}$ & 110.000 & 110.000 & 66.000 & & \\
\hline & 77.000 & 577.000 & 345.000 & & & & & \\
\hline
\end{tabular}

Figure 5. Mat 59 Material Card used in Model

$400 \mathrm{~N}$ force is applied to the tip of the upper plate as shown in figure 6 in dynamic loading simulation. Left end of uppr spring and right end of lower spring are fixded so they behave as cantilever beams.

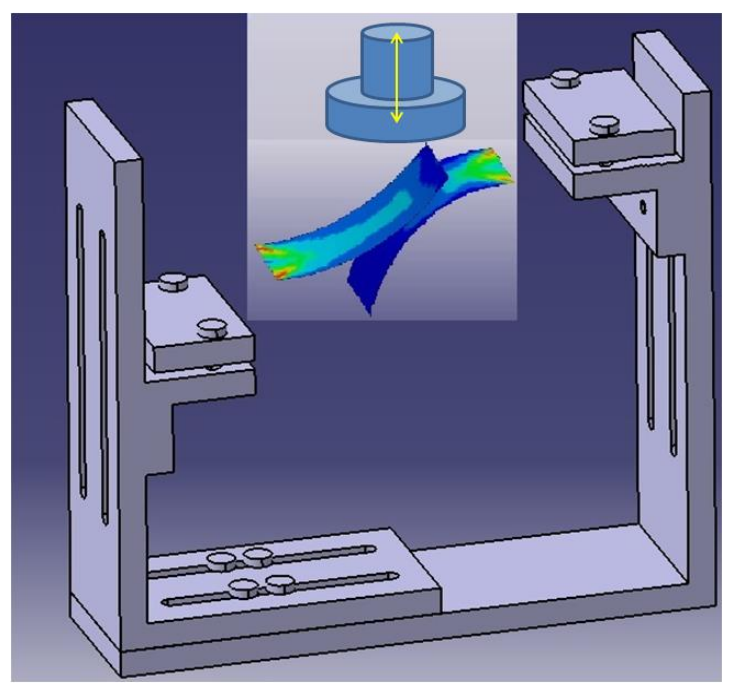

Figure 6. Bending test simulation environment

\section{RESULTS AND DISCUSSION}

The mechanical properties evaluated from the test performed are tabulated in table 3.1. These paremeters are used in numerical study. The material model MAT59 needs most of them. This type of material models are widelyb used in literature [18].

Ansys Ls Dyna dynamic loading simulations are perfomed and $\mathrm{Z}$ displacement, $\mathrm{Z}$ velocity and $\mathrm{Z}$ acceleration characteristic are obtainded. Simulation result are shown in figure 7-9 respectively.

Point A on upper spring is given in figure 9. For this point $\mathrm{Z}$ displacement versus time graph is given in figure 10 .

Load-time data is available. After the numerical studies in Ansys Ls-Dyna are completed, force-time graph of the springs is given in figure 11. Thus, the non-linear characteristic can be seen clearly. Studies show that the leaf springs are damaged in about 500 Newton. Maximum displacement is $24 \mathrm{~mm}$. 
Table 3.1. Composite material properties

\begin{tabular}{lc}
\hline Composite material properties, unit & Value \\
\hline Longitudinal tensile strength a-axis, MPa & 577 \\
Transverse tensile strength b-axis, MPa & 577 \\
Normal tensile strength c-axis, MPa & 345 \\
Longitudinal compression strength a-axis, & 110 \\
MPa & \\
Transverse compression strength b-axis, & 110 \\
MPa & 66 \\
Normal compression strength c-axis, MPa & 630 \\
In plane shear strength, MPa & 130 \\
Transverse shear strength, MPa & 78 \\
Transverse shear strength, MPa & 78 \\
Young's modulus - longitudinal direction & 10130 \\
(Ea), MPa & \\
Young's modulus - transverse direction & 10130 \\
(Eb), MPa & \\
Young's modulus - normal direction (Ec), & 6066 \\
MPa & \\
Shear modulus (Gab), MPa & 1530 \\
Shear modulus (Gbc), MPa & 916 \\
Shear modulus (Gca), MPa & 916 \\
Poisson ratio along XY-direction (Vba) & 0,154 \\
Poisson ratio along YZ-direction (Vca) & 0,092 \\
Poisson ratio along ZX-direction (Vcb) & 0,092 \\
Mass density of the material, g/cm ${ }^{3}$ & 1,140
\end{tabular}

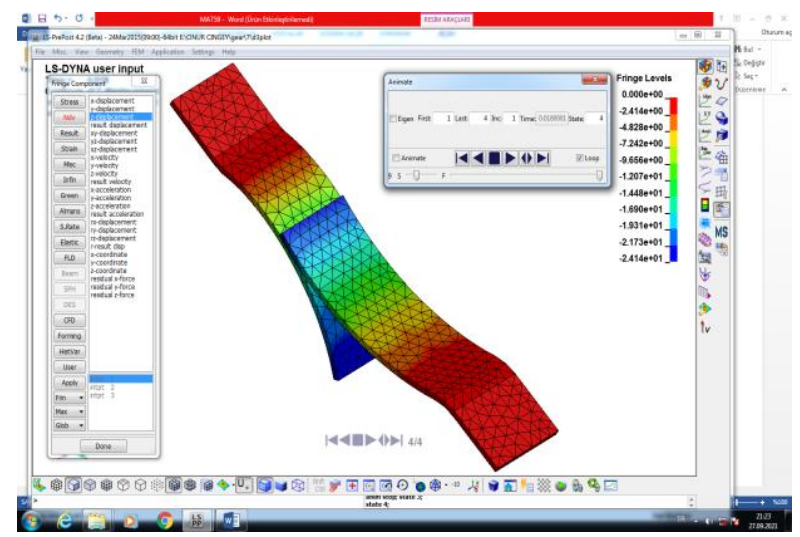

Figure 7. Z Displacement in bending test in LS-Dyna program

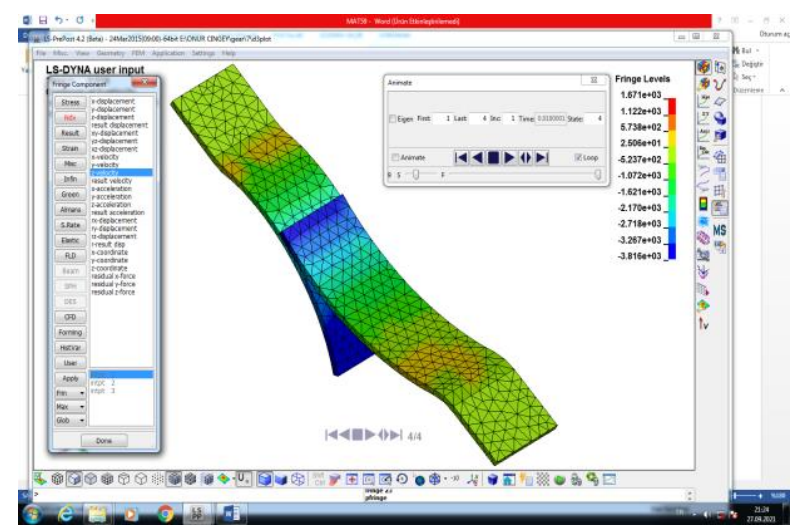

Figure 8. Z Velocity in bending test in LS-Dyna program

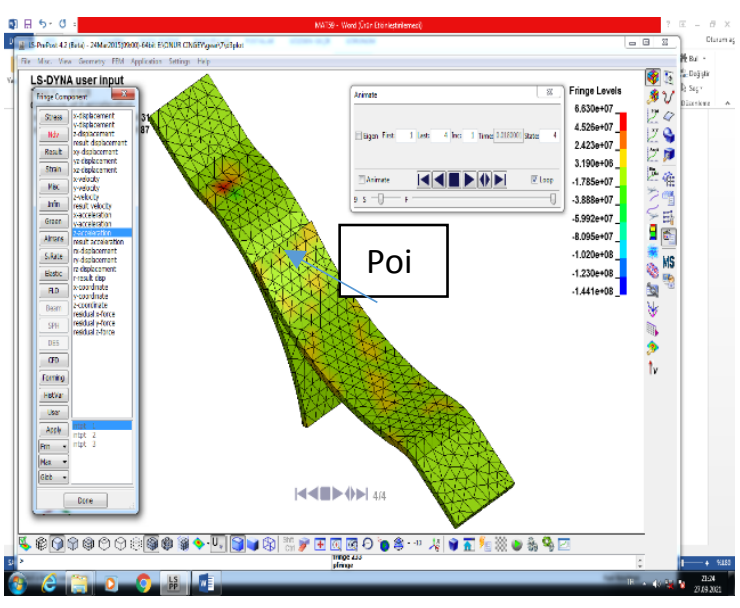

Figure 9. Z Acceleration in bending test in LS-Dyna program

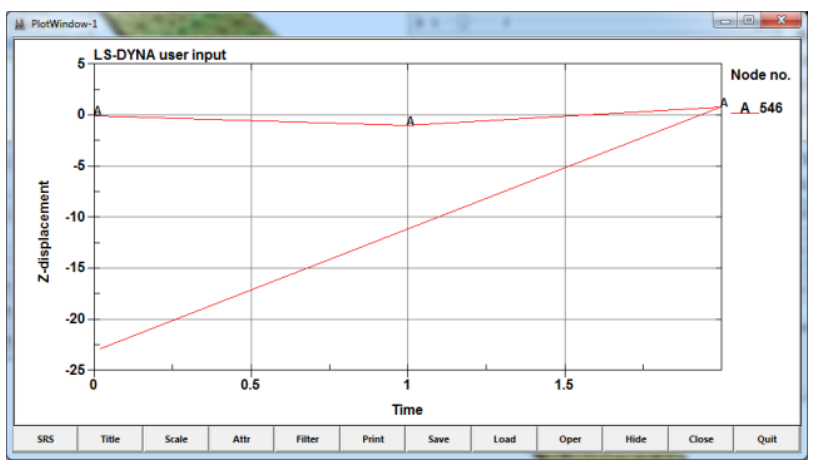

Figure 10. Z Displacement at Point A in bending test in LS-Dyna program

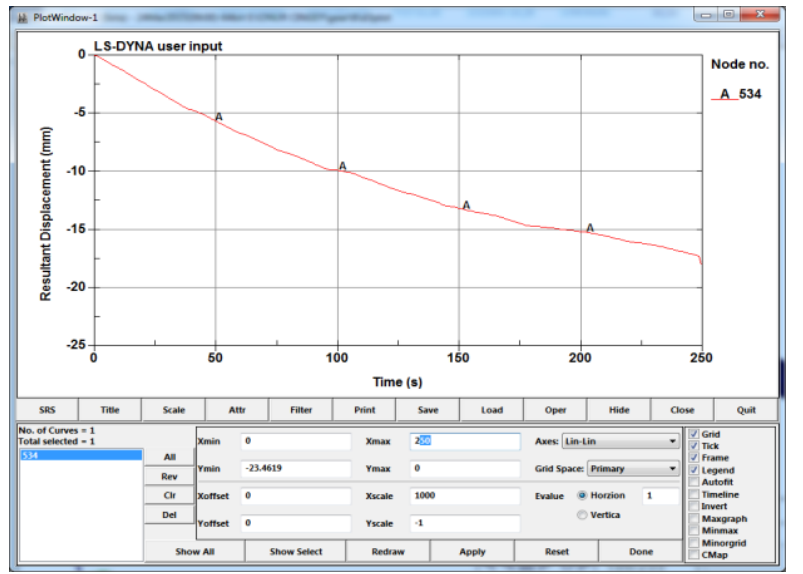

Figure 11. Load-time relation for composite leaf spring

\section{CONCLUSIONS}

In this study, design and analysis of a laminated composite spring having non-linear elastic characteristic was performed, Ansys Ls-Dyna software is used for these numerical simulations

It was observed that the force-displacement curves for single leaf spring having involute profile is linear elastic in the load range of this study. When two leaf 
spring are arranged in the assembly similar to gear mate, they show non linar elastic behavior. The reason for this is variable support point of the second spring with respect to other. Since the moment arm is a function of load applied then the stiffness of spring become a progressively hardening type.

This study claimed out that it is possible to obtain desired load-elongation characteristics by means of a proper profile design for a composite leaf spring. The vibration and fatigue characteristics of such a structure is still under investigation in Mechanical Engineering laboratories of Marmara University.

\section{ACKNOWLEDGEMENT}

We would like to thank Marmara University Scientific Research Projects Commission for their financial support to our FEN-C-YLP-131217-0682 project.

\section{REFERENCES}

[1] Materials and Man's Needs Materials Science and Engineering -- Volume I (1975), The History, Scope, and Nature of Materials Science and Engineering

[2] Rajagopal D., Varun S., Manikanth M., Bysani S.S.K. (2014) Automobile Leaf Springs from Composite Materials, International Journal of Engineering and Advanced Technology (IJEAT), 4 (1), 2249-8958.

[3] Ekbote T., Sadashivappa K.S., and Abdul Budan D., (2012) Optimal Design and Analysis of Mono Leaf Composite Spring by Finite Element Analysis, In: IEEE-International Conference On Advances In Engineering,Science And Management (lCAESM ) March 30.31,2012, paper no. 06216232, page.1-6, Arizona State Universit.

[4] Carlsson L. A., Adams D. F., Pipes R. B., (2013) Basic Experimental Characterization of Polymer Matrix Composite Materials, Polymer Reviews, 53 (2), 277-302.

[5] Ahmed Mohamed Elmarakbi, Wiyao Leleng Azoti (2015) "Novel composite materials for automotive applications: concepts and challenges for energy-efficient and safe vehicles" 10th International Conference on Composite Science and Technology ICCST/10 At: Lisboa Portugal.

[6] ASTM Standard D3039/D3039M-17:2017. Standard Test Method for Tensile Properties of Polymer Matrix Composite Materials. American Society for Testing and Materials, West Conshohocken, USA.

[7] http://www.performancecomposites.com/carbonfibre/mechanicalpropertie s_2.asp
[8] Andrew Y. Chen, Sebastian Baehr, Austin Turner, Zilan Zhang, Grace X. Gu (2021) "Carbon-fiber reinforced polymer composites: A comparison of manufacturing methods on mechanical properties", International Journal of Lightweight Materials and Manufacture (4) 4, 468-479.

[9] Ashwini K., Mohan Rao C.V., (2018) "Design and Analysis of Leaf Spring using Various Composites - An Overview" Materials Today: Proceedings Volume 5, Issue 2, Part 1, 5716-5721

[10] ASTM D3039 / D3039M - 17 Standard Test Method for Tensile Properties of Polymer Matrix Composite Materials American Society for Testing and Materials, West Conshohocken, USA

[11] ASTM Standard D6641/D6641M-16:2017. Standard Test Method for the Compressive Properties of Polymer Matrix Composite Laminates Using a Combined Loading Compression (CLC) Test Fixture. American Society for Testing and Materials, West Conshohocken, USA.

[12] ASTM Standard D7078/D7078M - 12:2012. Standard Test Method for Shear Properties of Composite Materials by V-Notched Rail Shear Method, American Society for Testing and Materials, West Conshohocken, USA.

[13] Lahey T. J., Heppler G. R. (2002) Mechanical Modeling of Fabrics in Bending, ASME International Mechanical Engineering Congress \& Exposition, 71 (1), 173-180

[14] Can, B. (2011) Evaluation of Tabbed Composite Specimens for Material Characterization under Medium Loading Rates - A Numerical Study. MSc Thesis, Istanbul Technical University, Istanbul, Turkey, 20-37.

[15] LS-DYNA® Theory Manual (r: 10859) LSDYNA Dev (2019) Livermore Software Technology Corporation (LSTC), California, USA.

[16] LS-DYNA® Keyword User's Manual Volume I (r:11209) LS-DYNA Dev (2019) Livermore Software Technology Corporation (LSTC), California, USA.

[17] LS-DYNA® Keyword User's Manual Volume II (r: 11208) LS-DYNA Dev (2019) Livermore Software Technology Corporation (LSTC), California, USA.

[18] N Kılıç, B Ekici, S Bedir (2017) Optimization of high hardness perforated steel armor plates using finite element and response surface methods Mechanics of Advanced Materials and Structures 24 (7), 615-624. 